\title{
AUTOMATIC ENVIRONMENTAL-CONTROL IN THE BIOSYSTEM FOR SPROUTING SOILLESS HYDROPONICS BARLEY
}

\author{
Khaled K. Hegab*
}

\section{ABSTRACT}

Air temperature and lighting time are considered main elements in sprouting and growth biosystems environment. High and low temperature stresses have dangerous effects on quality and quantity of plants. Long and short time of lighting cause disturbance in photosynthesis processes. Importing automatic systems for controlling the environmental elements is very expensive. To determine the suitable conditions inside the biosystem, three levels of temperature, three levels of daily lighting time, and two varieties of barley were studied through complete randomized trial. Giza 126 and Giza 128 varieties were studied as models for six and two-row barley. Electric control system for adjusting air temperature and managing lighting time inside sprouted chamber was locally designed and fabricated. Water use efficiency, percentages of dry matter, ash, crude protein, ether extract, crude fiber and nitrogen free extract were used as criteria of sprouted production quality. Statistically, fixing the sprouted green barley chamber on $20^{\circ} \mathrm{C}$ and $12 \mathrm{~h}$ per day is considered the best condition for the six and two-row barley under the soilless hydroponics conditions. To evaluate the quality of the produced green fodder, growth experiment on four groups of lambs was carried out. The results showed that using rations containing sprouted green barley gave higher values of final body weight, total gain and average daily gain.

Keywords: Automatic control, environmental conditions, soilless hydroponics, sprouted barley.

\section{INTRODUCTION}

utomatic control systems are considered critical components for
managing engineering operations and storing beneficial data in
the agricultural production systems, Peralta et al. (2010), Park et al. (2011), Park and Kim (2012), Yang et al. (2013), Rau et al. (2015), Algarín et al. (2017) and Jianyun et al. (2017).

Agric. Eng. Dept., Fac. of Agric., Cairo U, 12613, Giza, Egypt 
Environmental-control processes inside the sprouting and growth chambers are considered critical issue affecting on quality and quantity of production. The high rates of the chamber temperature consume big amount of the stored nutrition inside the grains and decrease the fresh fodder yield, Rykaczewska (2017). Low and high temperatures directly affect photosynthesis, vegetation growth and fresh weight, Rodríguez et al. (2015). Specifically, low temperature stress is one of the main abiotic factors that reduce the productivity of many crops in hilly areas around the world, Perveen et al. (2013). Long time of lighting causes plants photo-toxicity due to disturbance in photosynthesis processes. Short time of lighting leads to yellow color and weakness in vegetation growth due to shortage in photosynthesis processes, Barczak-Brzyzek et al. (2017). Barley crop is considered an ideal green fodder that could be produced by using soilless hydroponics systems, Hegab (2017a) and Hegab (2017b). Six and two rows of grains in spike are considered two main groups of barley varieties in Egypt. Therefore, the main objective of this research is to determine the ideal temperature and lighting time for sprouting the two groups of varieties. Since the sprouting chamber is closed environmental system managing different types of processes which, continuously produce gases, water vapor and heat. Therefore, the manual control of the system environment is very impossible. Using imported equipment for automatic control in the environmental conditions of the sprouting and growth chambers is not economic for the agricultural production systems. Importing automatic-control equipment means losses of employment chance from the local market. Therefore, automatic-control system was locally designed according to closed-loop electric control system idea. The system components were purchased from local market and installed by local technicians. Food security exists when all people, at all times, have physical, social, and economic access to sufficient, safe and nutritious food which meets their dietary needs and food preferences for an active and healthy life. Food insecurity exists when people do not have adequate physical, social, or economic access to food, FAO (1996) and FAO (2002). Therefore, the sprouting green-fodder production systems are considered effective element in food security issue. Due to technical, 
economic and social factors, "design, fabrication and using automatic control systems to manage different operations such as irrigation processes, fertigation programs and environmental conditions" are considered critical issue in vegetables and green fodders hydroponics production-systems, Neto et al. (2014), Dominguez et al. (2012) and Miyoshi et al. (2016). Historically, hydroponic production considers an old method "more than 50 years" of plants cultivating without soil. The knew-how in this technique is to provide the best growth of cultivated plants through well control in nutrient requirements and availability of water, Atlas Global Crop (2004) and Ghazi (2012). Due to the scarcity of water in the arid regions decreasing the arable land cultivated with green fodder contagiously occur. As a result, decreasing animal numbers and increasing the gap between supply and demand in food are revised marked. So, developing nontraditional system for green fodder production by using deficit water resources such as hydroponics, is needed. In the same context, green forage is considered a limiting factor in livestock production sector, especially in arid and semi-arid areas with scarcity of pasture and limited water. So, researchers try always to provide non-conventional sources of feed such as sprouted grains by hydroponic technique. Sprouting is a simple method to germinate the seeds to enhance their feeding value, Khattak et al. (2007). Also, sprouted green forage could be produced from cereal and legume seeds. However, barley grains are popular because of their price and availability around the world. Studies related to using sprouted green-barley in animal feeding remarked that, crude protein content in the fresh matter is around 16 to $17 \%$. Digestibility was more $85 \%$ in In vitro study. Using sprouted barley in the diet of growing lambs and ewes improved the performance, Eshtayeh (2004) and Fayed (2011). Sprouted green-forage contains increased livestockanimal fertility because it contains high percentage of vitamin $\mathrm{E}$ and beta carotene, Atlas Global Crop (2004). Despite these numerous benefits of sprouted green fodder, this point still needs more studies to verify that it can be used to replace part of a whole diet not only green fodder needed. So, this study aims to investigate using of sprouted green barley in growing-lamb diet $(0,20 \%, 40 \%$ and $60 \%$ from total 
dry matter intake) on growth performance, digestibility, rumen and blood parameters.

\section{MATERIALS AND METHODS}

\subsection{Experimental Design, Engineering Treatments and Statistical}

Analysis: The completely randomized design was used with eighteen treatments and five replicates for determining suitable air temperature and lighting time inside the sprouting barley biosystem. For achieving the complete randomization, the collected data were statistically analyzed as Arc SIN data using SPSS program. Probabilities of significance among treatments and LSD $(\mathrm{P} \leq 0.05)$ were used to compare means among treatments. However, the trial design with its details is shown in Table (1), Landauk, Everitt (2004) Toutenburg, Shalabh (2009). Three levels of temperature, three levels of daily lighting time, and two varieties of barley were studied. Giza 126 and Giza 128 varieties were studied as models for the six and two-rows barley. Copper nutrient solution with concentration of $2 \%$ was used. Irrigation system was managed on 60,54, and 30 second per 6 hours through the first three days, the second three days and the third three days respectively. Consumed Water (CW) "1/tray per cycle", Fresh Weight of green fodder (FW) "kg/tray", Dry Matter (DM) "g”, Dry Matter Percentage (DMP), Water Use Efficiency (WUE) "gram of dry matter /liter of water", Ash $(\%)$, Crude Protein $\left(\mathrm{C}_{\mathrm{P}}\right)$, Ether Extract (EE), Crude Fber (Cf), and Nitrogen Free Extract (NFE) were measured in each sample. Agric. Eng. Dept. Lab., Animal Nut. Dept. Lab. and Res. Complex Labs. in the Fac. of Agric. , Cairo U were used for analyzing collected samples.

2.2 Automatic-Control Systems Design and Installation: The green fodder production trials of the soilless sprouted barley were executed inside the hydroponics green fodder chamber located in. the Agric. Eng. Dept., Cairo University. The chamber air-temperature and lighting time were automatically controlled using electric control system. Fig. (1) summarizes the overall idea for controlling on temperature and light intensity inside the green fodder chamber. The idea depends on the Multi-Loop closed-loop electric control system to manage temperature and light. 
Table (1): Experimental Design for investigating suitable Air Temperature and Lighting Time inside the Green Fodder Chamber:

\begin{tabular}{|c|c|c|c|c|}
\hline & $\begin{array}{c}\text { Daily Lighting Time } \\
\text { (hour) }\end{array}$ & \multicolumn{3}{|c|}{ Air Temperature } \\
\cline { 2 - 5 } & $\mathbf{1 5}^{\mathbf{}} \mathbf{C}$ & $\mathbf{2 0}^{\mathbf{}} \mathbf{C}$ & $\mathbf{2 5}^{\mathbf{}} \mathbf{C}$ \\
\hline \multirow{2}{*}{$\begin{array}{c}\text { First Variety } \\
\text { Giza 126 } \\
\text { (Six rows barley) }\end{array}$} & $10 \mathrm{~h}$ & $\mathrm{~T}_{1}$ & $\mathrm{~T}_{2}$ & $\mathrm{~T}_{3}$ \\
\cline { 2 - 5 } & $12 \mathrm{~h}$ & $\mathrm{~T}_{4}$ & $\mathrm{~T}_{5}$ & $\mathrm{~T}_{6}$ \\
\hline \multirow{2}{*}{$\begin{array}{c}\text { Second Variety } \\
\text { Giza 128 }\end{array}$} & $14 \mathrm{~h}$ & $\mathrm{~T}_{7}$ & $\mathrm{~T}_{8}$ & $\mathrm{~T}_{9}$ \\
\cline { 2 - 5 } (Two rows barley) & $10 \mathrm{~h}$ & $\mathrm{~T}_{10}$ & $\mathrm{~T}_{11}$ & $\mathrm{~T}_{12}$ \\
\cline { 2 - 5 } & $12 \mathrm{~h}$ & $\mathrm{~T}_{13}$ & $\mathrm{~T}_{14}$ & $\mathrm{~T}_{15}$ \\
\hline
\end{tabular}

The desired light or temperature is considered the unique input and the actual light or temperature is considered the unique output for this loop. Transformers, diodes, transistors, capacitors, and relays are considered the main components of this systems, Xu et al. 2016, Wikibooks (2013), Petruzella (2010), Herman (2010), Moeller (2011), Young et al. (2008), Haines, Hittle (2006), Bern and Olson (2002). The desired light or temperature is manually entered by fixing the variable resistors or automatically entered by using computer. Fig. (2) shows the developed design of electric-control system circuits for managing light inside sprouting and growth chamber. This system consists of transformer, bridge rectifier, timer, relay and light emitting diode (LED) lamps. Length, diameter, needed power and luminous flux of the LED lamps are $120 \mathrm{~cm}, 32 \mathrm{~mm}, 40 \mathrm{~W}$ and $4000 \mathrm{~lm}$ respectively. Luminous flux incident on the room surface (Illuminance) were $0.0,4000,8000 \mathrm{~lm}$ for the first, second, and third three days of the life cycle. The closed loop timer cm, was fixed on 10, 12 and 14 hour lighting time through the sprouting trails. Fig. (3) shows the developed design of electric-control system circuits for fixing temperature inside sprouting and growth chamber. This system consists of transformer, bridge rectifier, resistors, transistors, relay, heat exchanger, and sensors. The closed loop resistors were fixed for 15,20 and $25^{\circ} \mathrm{C}$ through the sprouting trials. The two control systems were specially designed for this purpose. The components of the two closed-loop systems were purchased from the local market. The installation process was done by local electronic technicians in Egypt. 


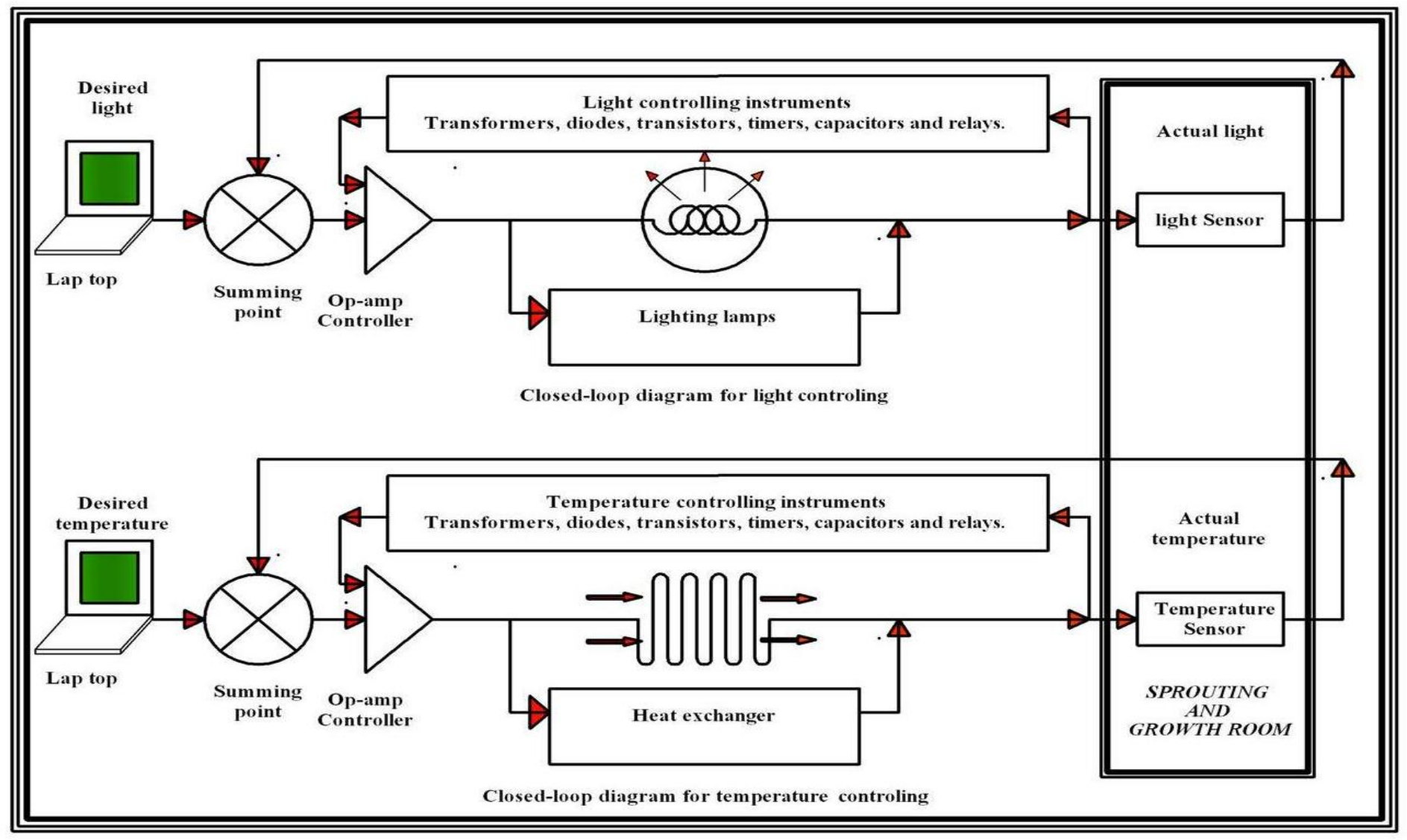

Fig. (1): Closed-loop idea for electric control systems design. 


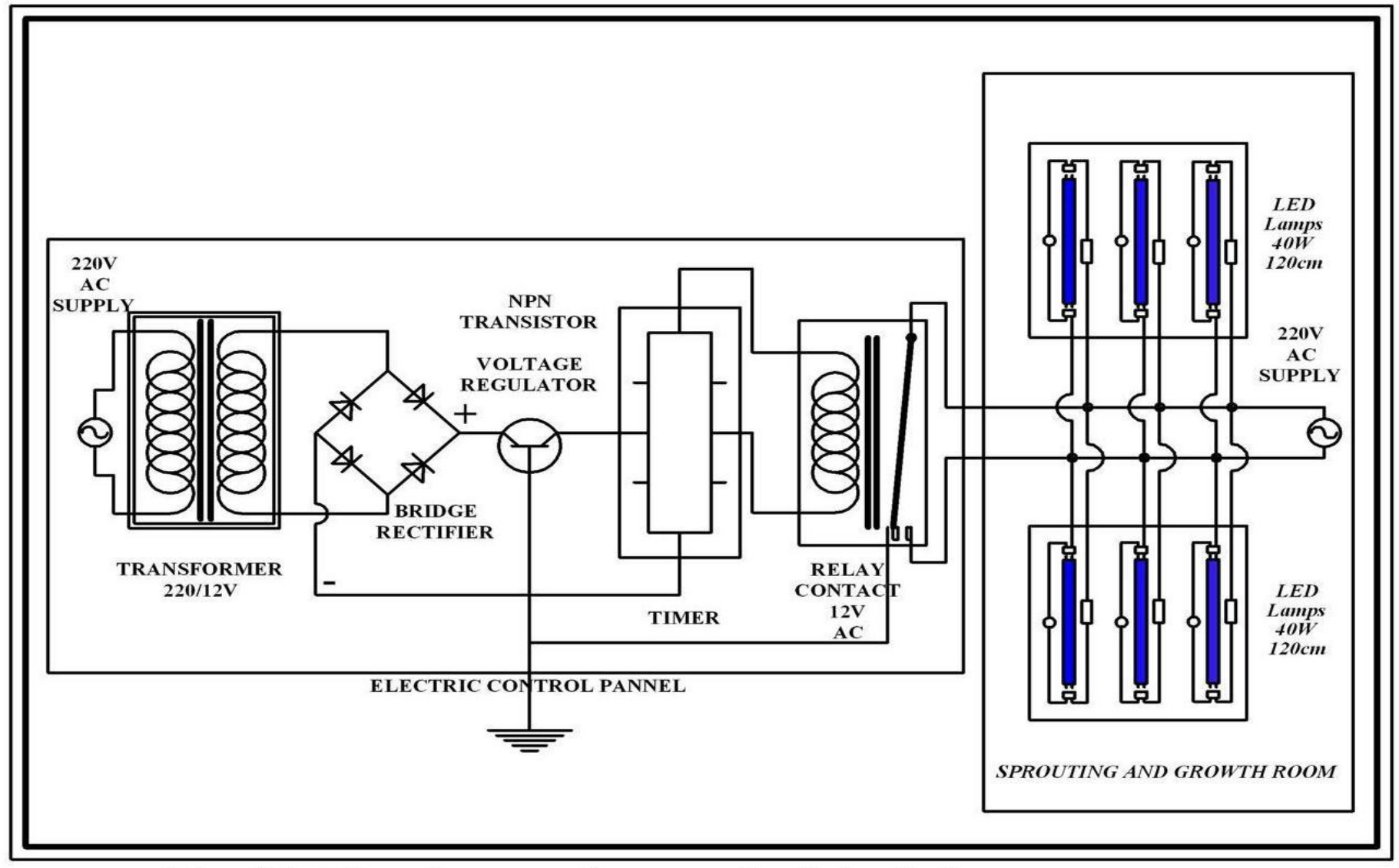

Fig. (2): Electric control system for light timing management. 


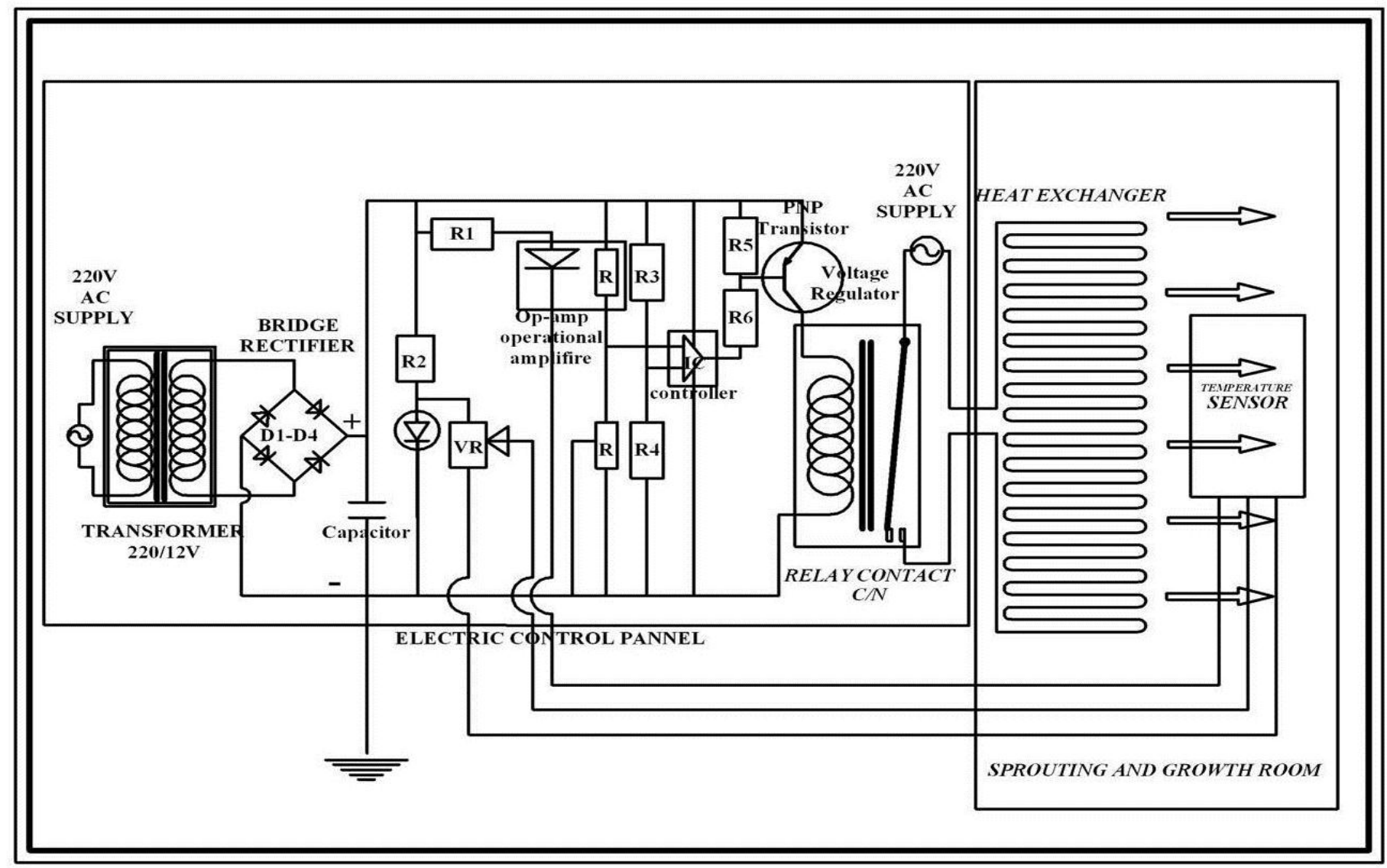

Fig. (3): Electric control system in air temperature. 
2.3 Growth Experiment Design: Twenty eight Rahmani lambs strain were divided into 4 groups in growth trial for 90 days. Lambs in control group (LGR1) were fed clover hay plus concentrate feed mixture. Ratios of $20 \%, 40 \%$ and $60 \%$ of ration dry matter were substituted with fresh sprouted barley for animals of LGR2, LGR3 and LGR4. The recorded data from the growth trial were analyzed using the general linear model procedure of SAS (2001). The differences among means were ranked according to Duncan's New Multiple Range Test, Duncan (1955).

\section{RESULTS AND DISCUSSIONS}

3.1 Engineering Management and Production Quality: Table (2) shows the effects of temperature and daily lighting time on technical specifications of the soilless hydroponics for sprouted six rows barley "Giza 126". Basically, the sprout green fodder technical specifications such as "water use efficiency, dry matter, crude protein, ether extract, crude fiber, nitrogen free extract" were used as main criteria to determine the best treatment. Generally, the tabulated values of these criteria are small at low levels of temperature and lighting time $\left(15^{\circ} \mathrm{C}\right.$ and $\left.8 \mathrm{~h}\right)$. This is because at low levels of temperature and daily lighting time, the activation rates of the plants physiological processes are decreased. Irreversibly, the tabulated values of these criteria are small at high levels of temperature and lighting time $\left(25^{\circ} \mathrm{C}\right.$ and $\left.14 \mathrm{~h}\right)$. This is because at high levels of temperature, the demolition processes are increased. Also, the long lighting time (14h) is not suitable with the winter crops such as barley. Exactly, the means of water use efficiency, percentages of dry matter, ash, crude protein, ether extract, crude fiber and nitrogen free extract in the treatment "No. 5" were 108.63, 15.8, 3.5, 15.6, 13.0, 3.1, and 64.8 respectively. These values are higher than values in the other treatments at $(\mathrm{P}<0.05)$. Therefore, the treatment number 5 with technical specifications at $\left(20^{\circ} \mathrm{C}\right.$ and $\left.12 \mathrm{~h}\right)$ is considered the best for the six rows barley under the soilless hydroponics conditions. This result is in agreement with, El-Deeba et al. 2009, Edwards (2010), Al-Karaki, Fazaeli et al. (2012) and Adglane et al. (2016). Table (3) shows the effects of temperature and daily lighting time on technical specifications of the soilless hydroponics sprouted two rows barley "Giza 128". 
Table (2): Effects of temperature and lighting duration on the six rows sprouted barley.

\begin{tabular}{|c|c|c|c|c|c|c|c|c|c|c|}
\hline & CW & FW (kg) & DM (g) & $\operatorname{DMP}(\%)$ & WUE (g/l) & $\operatorname{Ash}(\%)$ & Сp (\%) & Cf (\%) & EE (\%) & NFE (\%) \\
\hline $\mathbf{T}_{1}$ & 8.00 & $4.450^{\mathrm{b}}$ & $548^{c}$ & $12.3^{\mathrm{d}}$ & $68.50^{\mathrm{e}}$ & $4.3^{\mathrm{a}}$ & $11.9 \mathrm{e}$ & $14.1^{\mathrm{b}}$ & $3.5^{\mathrm{bc}}$ & $66.2^{\mathrm{a}}$ \\
\hline $\mathbf{T}_{3}$ & 8.00 & $4.350^{\mathrm{b}}$ & $605^{\mathrm{c}}$ & $13.9^{c}$ & $75.63^{d}$ & $4.0^{\mathrm{a}}$ & $12.8 \mathrm{bc}$ & $14.5^{b}$ & $4.5^{\mathrm{a}}$ & $64.2^{c}$ \\
\hline$\underline{T}_{5}$ & 8.00 & $5.500^{a}$ & $869^{a}$ & $15.8^{\mathrm{a}}$ & $108.63^{\mathrm{a}}$ & $3.5^{\mathrm{b}}$ & $15.6^{\mathrm{a}}$ & $13.0^{\mathrm{c}}$ & $3.1 b^{c}$ & $64.8^{\mathrm{c}}$ \\
\hline$T_{6}$ & 8.00 & $4.250^{\mathrm{b}}$ & $612^{c}$ & $14.4^{\mathrm{bc}}$ & $76.50^{\mathrm{d}}$ & $3.6^{\mathrm{b}}$ & $14.3^{\mathrm{b}}$ & $14.3^{b}$ & $3.6^{\mathrm{b}}$ & $\overline{64.2^{c}}$ \\
\hline $\mathbf{T}_{7}$ & 8.00 & $4.500^{b}$ & $599^{c}$ & $13.3 c$ & $74.88^{\mathrm{d}}$ & $4.1^{\mathrm{a}}$ & $13.7 \mathrm{c}$ & $14.5^{b}$ & $3.7^{\mathrm{b}}$ & $64.0^{c}$ \\
\hline $\mathbf{T}_{9}$ & 8.00 & $4.250^{\mathrm{b}}$ & $574^{c}$ & $13.5^{\mathrm{c}}$ & $71.75^{d}$ & $4.5^{\mathrm{a}}$ & $12.9 \mathrm{de}$ & $15.9^{\mathrm{a}}$ & $4.5^{\mathrm{a}}$ & $62.2^{\mathrm{e}}$ \\
\hline$\pm \mathrm{SE}$ & ------ & 0.25 & 3.41 & 1.1 & 1.35 & 0.36 & 1.39 & 1.08 & 0.46 & 1.14 \\
\hline
\end{tabular}

Table (3): Effects of temperature and lighting duration on the two rows sprouted barley.

\begin{tabular}{|c|c|c|c|c|c|c|c|c|c|c|}
\hline & CW & FW (kg) & DM (g) & DMP (\%) & WUE (g/l) & Ash (\%) & Cp (\%) & $\operatorname{Cf}(\%)$ & EE (\%) & NFE (\%) \\
\hline $\mathbf{T}_{10}$ & 8.00 & $4.850^{\mathrm{b}}$ & $645.05^{\mathrm{de}}$ & $13.3^{\mathrm{de}}$ & $80.63 d$ & $4.1^{\mathrm{ab}}$ & $12.5^{\mathrm{d}}$ & $14.7^{\mathrm{a}}$ & $4.5^{\mathrm{a}}$ & $64.2^{\mathrm{b}}$ \\
\hline$T_{12}$ & 8.00 & $4.750 \mathrm{~b}$ & $655.5^{d}$ & $13.8^{d}$ & $81.93 \mathrm{de}$ & $4.2^{\mathrm{ab}}$ & $12.6^{\mathrm{d}}$ & $14.4^{\mathrm{ab}}$ & $4.2^{\mathrm{a}}$ & $64.6^{b}$ \\
\hline$\underline{T}_{14}$ & $\underline{8.00}$ & $\underline{5.750}^{\mathrm{a}}$ & $937.25^{\mathrm{a}}$ & $16.3^{a}$ & $117.15^{a}$ & $\underline{3.3}^{\text {bc }}$ & $15.4^{\mathrm{a}}$ & $13.4^{\text {bc }}$ & $3.4^{\mathrm{c}}$ & $\underline{64.5}^{b}$ \\
\hline$T_{15}$ & 8.00 & $4.650^{\mathrm{b}}$ & $664.95^{\mathrm{d}}$ & $14.3^{c}$ & $83.11 \mathrm{de}$ & $3.8^{\mathrm{b}}$ & $14.7^{b}$ & $14.1^{\mathrm{ab}}$ & $3.9^{\mathrm{b}}$ & $63.5^{c}$ \\
\hline $\mathbf{T}_{18}$ & 8.00 & $4.450^{\mathrm{bc}}$ & $609.65^{\mathrm{de}}$ & $13.7^{\mathrm{d}}$ & $76.20 \mathrm{e}$ & $4.3 \mathrm{a}^{\mathrm{b}}$ & $13.2^{\mathrm{cd}}$ & $14.8^{\mathrm{a}}$ & $4.1^{\mathrm{a}}$ & $63.6^{c}$ \\
\hline \pm SE & ------ & 0.52 & 3.5 & 0.87 & 1.39 & 0.42 & 1.07 & 0.57 & 0.44 & 0.64 \\
\hline
\end{tabular}


Specifically, the means of water use efficiency, percentages of dry matter, ash, crude protein, ether extract, crude fiber and nitrogen free extract in the treatment "No. 14" are 117.15, 16.3, 3.0, 15.4, 13.4, 3.4, and 64.5 respectively. These values are higher than the other treatments at $(\mathrm{P}<0.05)$. Therefore, the treatment number 14 with technical specification $\left(20 \mathrm{C}^{\circ}\right.$ and $12 \mathrm{~h}$ ) is considered the best for the two rows barley under the soilless hydroponics conditions. This result is in agreement with, Edwards (2010), Al-Karaki, Al-Hashimi (2011), Fazaeli et al. (2012) and Adglane et al. (2016).

Chemical composition results showed that green barley was higher in crude protein compared to $\mathrm{CFM}$ and $\mathrm{CH}$ on dry matter basis. Crude fiber in barley was remarked lower than clover hay. Fiber fraction contents were higher in green barley compared to concentrate feed mixture and clover hay. Results of chemical analyses of green barley in present study were higher compared with others, Eshtayeh (2004), Global Atlas (2004) and Fazaeli et al. (2011).

In dealing with the two varieties "the six rows barley (Giza 126) and the two rows barley (Giza 128)", there are no significant differences $(\mathrm{P}<0.05)$ among the means of water use efficiency, percentages of dray matter, ash, crude protein, ether extract, crude fiber and nitrogen free extract in the two treatments "No. 5 and 14 " at $(\mathrm{P}<0.05)$. This result is because of the short life cycle "nine days" of the sprouted soilless hydroponics barley green fodder.

\subsection{Blood Parameters and Growth Performance of Lambs:}

The utilized sprouted barley in the growth trial animals was produced by using the six rows barley grains (Giza 126) under temperature of $20^{\circ} \mathrm{C}$ and $12 \mathrm{~h}$ daily hours. Table (4) indicate that values of blood chemical analysis were in the normal range of Lambs. Lambs group ration two (LGR2) showed higher significant values $(\mathrm{P}<0.05)$ in total proteins and albumin. Control ration (LGR1) showed slight higher value of urea concentration with insignificant differences with LGR2 and LGR3. No significant differences were observed among groups in globulin, creatinine Alanine Aminotransferase (ALT) and Aspartate Aminotransferase (AST). These results agree with Fayed (2011). 
Table 4: Performance of growing lambs.

\begin{tabular}{|c|c|c|c|c|c|}
\hline \multirow[b]{2}{*}{ Item } & \multicolumn{4}{|c|}{ Lambs groups } & \multirow[t]{2}{*}{$\pm \mathrm{SE}$} \\
\hline & LGR1 & LGR2 & LGR3 & LGR4 & \\
\hline \multicolumn{6}{|c|}{ Blood parameters } \\
\hline Total proteins, g/dl & $6.25^{\mathrm{b}}$ & $7.20^{\mathrm{a}}$ & $6.55^{\mathrm{ab}}$ & $6.40^{\mathrm{b}}$ & 0.22 \\
\hline Albumin, g/dl & $3.40^{\mathrm{b}}$ & $4.15^{\mathrm{a}}$ & $3.45^{\mathrm{b}}$ & $3.35^{\mathrm{b}}$ & 0.19 \\
\hline Globulin, g/dl & 2.85 & 3.05 & 3.10 & 3.05 & 0.07 \\
\hline Urea, mg/dl & $28^{\mathrm{a}}$ & $26.5^{\mathrm{ab}}$ & $27.5^{\mathrm{ab}}$ & $26^{\mathrm{b}}$ & 0.54 \\
\hline Creatinine, mg/dl & 0.95 & 0.8 & 0.95 & 0.75 & 0.7 \\
\hline ALT, IU/L & 23 & 23 & 23.5 & 22.5 & 0.74 \\
\hline AST, IU/L & 21 & 22 & 23.5 & 22 & 1.3 \\
\hline \multicolumn{6}{|c|}{ Growth performance } \\
\hline \multicolumn{6}{|l|}{ Live body mass: } \\
\hline Initial body mass, kg & 30.28 & 29.93 & 30.21 & 29.57 & 0.99 \\
\hline Final body mass, kg & $44.21^{\mathrm{b}}$ & $46.00^{\mathrm{ab}}$ & $47.93^{\mathrm{a}}$ & $47.93^{\mathrm{a}}$ & 1.43 \\
\hline Total weight gain, $\mathrm{kg}$ & $13.93^{\mathrm{b}}$ & $16.07^{\mathrm{ab}}$ & $17.71^{\mathrm{a}}$ & $18.36^{\mathrm{a}}$ & 0.89 \\
\hline Average daily gain, $\mathrm{g}$ & $154.76^{\mathrm{b}}$ & $178.57^{\mathrm{ab}}$ & $196.82^{\mathrm{a}}$ & $203.96^{\mathrm{a}}$ & 9.98 \\
\hline \multicolumn{6}{|l|}{ Feed intake, $\mathrm{kg} / \mathrm{h} / \mathrm{d}$} \\
\hline Concentrate & 0.87 & 0.71 & 0.55 & 0.36 & ---- \\
\hline Clover hay & 0.37 & 0.30 & 0.23 & 0.16 & ---- \\
\hline Green barley & ---- & 0.95 & 1.95 & 2.91 & ----- \\
\hline \multicolumn{6}{|c|}{ Feed intake, $\mathrm{kg} / \mathrm{h} / \mathrm{d}$. on DM basis } \\
\hline Total DM intake & 1.12 & 1.14 & 1.17 & 1.16 & ----- \\
\hline \multicolumn{6}{|l|}{ Feed conversion, g/g: } \\
\hline DMI/ daily gain & 7.23 & 6.38 & 5.94 & 5.96 & $\begin{array}{ll}---- \\
\end{array}$ \\
\hline
\end{tabular}

Where: LGR: Lambs Group Ration, ALT: Alanine Aminotransferase, AST: Aspartate Aminotransferase, DMI: dry matter intake.

Lambs Groups fed rations, including green barley, showed higher values of final body weight, total gain and average daily gain. Dry matter intake was approximately the same among the four groups of rations lambs. Feed conversion was higher with groups fed grain barley compared to LGR1. Feeding on grain barley increased economic values by $31 \%, 27 \%$ and 15\% with LGR4, LGR 3 and LGR 2 respectively compared to control group (G1). These results agree with Eshtayeh (2004), Ghoneem (2010), and Fayed (2011). 


\section{CONCLUSION}

There were significant differences among the treatments in the production experiments. Lower and higher levels of temperature and lighting time than $\left(20^{\circ} \mathrm{C}\right.$ and $12 \mathrm{~h} /$ day $)$ are not suitable for sprouting the two and six barley. Therefore, managing the internal condition of the sprouted green fodder chamber on $\left(20^{\circ} \mathrm{C}\right.$ and $12 \mathrm{~h} /$ day $)$ is considered the best condition for the two and six rows barley.

Because of there are no significant differences among the sprouts technical specifications of the six rows barley (Giza 126) and the two rows barley (Giza 128). Therefore, sprouting any variety of the two groups gives approximately the same quantity and quality.

Blood parameters did not show any hazard effect of sprouted barley compared with control diet. Growth experiment results showed that using rations containing sprouted green barley gave higher values of final body weight, total gain and average daily gain without significant effect on feed intake. Therefore, using rations containing sprouted green barley from 20 to $60 \%$ for feeding lambs is recommended.

\section{REFERENCES}

Adglane, S. K., A. Serir, M. Bafdel and R. Benhacine 2016, Techno economic approach to hydroponic forage crops: use for dairy cattle herd, J. of Appl. Convention Biol. Sci. 3(6):Pp83-87. www.textroad.com

Algarín C. R., J. C. Cabarcas and A. P. Llanos 2017, Low-Cost Fuzzy Logic Control for Greenhouse Environments with Web Monitoring, Electronics 2017, 6, 71:Pp 1-12 doi:10.3390/electronics6040071

Al-Karaki G. N. and M. Al-Hashimi 2011, Green fodder production and water use efficiency of some forage crops under hydroponics conditions, International scholarly research network, volune 2012, Pp 1-5.

Atlas Global Crop. LTD. 2004, Feeding Animal to feed People. Retrieved from: World Wide Web: www.atgloco.com.

Bern, C. B. and D. I. Olson 2002. Electricity for Ag. Application, Iowa State Press, A Blackwell Publishing Company, 2121 State Avenue, Ames, Iowa 50014. 
Dominguez D. S., H.W. Takahashi, C. A. P. Camara and S. L. Nixdorf 2012, Automated system developed to control $\mathrm{pH}$ and concentration of nutrient solution evaluated in hydroponic lettuce production, Computers and Electronics in Agriculture, Volume 84:Pp 53-61.

Duncan, D. B. 1955, Multiple range and multiple F test. Biometrics, 11:1-42.

Edwards, J. 2010, Barley growth \& development, Industry \& Investment NSW District Agronomist (Cowra), State of New South Wales through Department of Industry and Investment (Industry \& Investment NSW). http://www.industry.nsw.gov.au

El-Deeba, M. M., El-Awady, M. N., Hegaz, M. M., Abdel-Azeem, F. A. and M. M. El-Bourdiny 2009. Engineering factors affecting hydroponics green fodder production. Misr Journal of Agricultural Engineering, 26 (3):Pp1647-1666.

Eshtayeh, F. A. I. 2004. A new source of fresh green feed (Hydropnic barley) for Awass sheep. Master in Environmental sciences, Fac. of Graduate studies, at An Najah National Uni., Nablus, Palestine.

FAO, 1996. Rome Deliration on World Food Security and World Food Summit Plan of Action, World Food Summit 13-17 November 1995, Rome.

FAO, 2002. State of Food Insecurity in the World 2001, Rome.

Fayed, M. A. 2011. Comparative study and feed evaluation of sprouted barley grains on rice straw versus Tamarix Mannifera on performance of growing Barki Lambs in Sinai. Journal of American Science. 7:Pp954-961.

Fazaeli, H., Golmohammadi, H. A., Shoayee, A. A., Montajebi, N. and Sh. Mosharraf 2011. Performance of feedlot calves fed hydroponics fodder barley. Journal of Agricultural Science and Technology, 13:Pp367-375.

Fazaeli, H., H.A. Golmohammadi, S.N. Tabatabayee and M. Asghari-Tabrizi 2012, Productivity and Nutritive Value of Barley Green Fodder Yield in Hydroponic System, World Applied Sciences Journal 16 (4):Pp531-539.

Ghazi N. Al-Karaki and M. Al-Hashimi 2012, Green Fodder Production and Water Use Efficiency of Some Forage Crops under 
Hydroponic Conditions, International Scholarly Research Network, ISRN Agronomy, Volume 2012, Article ID 924672, 5 pages.

Ghoneem and M. A. Wafaa 2010. Biological treatment of some agricultural and agroindustrial residues and their effects on performance of growing lambs. Ph.D. Thesis, Fac. of Agric., Cairo Univ. Egypt:Pp1-121

Herman S. L. 2010, Electric Motor Controls, Ninth Edition, 5 Maxwell Drive Clifton Park, NY 12065-2919 USA, http://opac.vimaru.edu.vn/edata/EBook/TNBook/TL\%20tong\%20hop/Control/9781435485754.pdf

Haines R. W. and D. C. Hittle 2006. Control systems for healthing, ventilating, and airconditioning sixth edition, (Springer Science+Business Media, Inc., 233 Spring Street, New York, NY 10013, USA):Pp 1-359.

Hegab K. K. 2017a, Rice straw recycling for developing the hydroponics sprouted barley production and conserving the environment, Misr J. of Agric. Eng. 34 (4-1): Pp 1897 - 1922.

Hegab K. K. 2017b, Successive management programs for the deficit water resources in hydroponics and soilless green fodder production, Misr J. of Agric. Eng. 34 (4-1):Pp 1869 - 1896.

Khattak A. B., Z. Aurang, B. Nizakat, A. K. Shahid, and S. K. Mohammad 2007. Influence of germination techniques on phytic acid and polyphenols content of chickpea (Cicer arietinum L.) sprouts. Food Chemistry, 104, 1074-1079.

Landau S. and B. S. Everitt 2004, A Handbook of Statistical Analyses using SPSS, by Chapman \& Hall/CRC Press LLC, SPSS U.K. Ltd., 1st Floor St. Andrew's House, West Street Woking, Surrey, United Kingdom GU21 6EB :Pp 1-339.

Jianyun C., S. Yunfan and L. Chunyan 2017, Research on Application of Automatic Weather Station Based on Internet of Things, IOP Conf. Series: Earth and Environmental Science 104 (2017) 012015, doi:10.1088/1755-1315/104/1/012015

Miyoshi T. and Y. Ibaraki and Y. Sago 2016, Development of an Android-tablet-based system for analyzing light intensity distribution on a plant canopy surface, Computers and Electronics in Agriculture, Volume 122:Pp 211-217. 
Moeller 2011, Wiring Manual, Eaton Industries GmbH, 53105 Bonn, Germany. http://www.moeller.net/binary/schabu/wiring_man_en.pdf

Neto A. J. S., S. Zolnier and D. C. Lopes 2014, Development and evaluation of an automated system for fertigation control in soilless tomato production, Computers and Electronics in Agriculture, Volume 103:Pp 17-25.

Park D., B. Kang, K. Cho, C. Shin, S. Cho and J. Park 2011, A Study on Greenhouse Automatic Control System Based on Wireless Sensor Network, Wireless Personal Communications, Volume 56, Issue 1:Pp 117-130

Park D., K. Son, and S. Kim 2012, A Design of Plant Factory Environment Control System, LNEE 180, Springer Science+Business Media Dordrecht 2012: Information Technology Convergence, Secure and Trust Computing, and Data Management :Pp. 15-20 DOI: 10.1007/978-94-007-5082-1_3,

Peralta L.M. R., L.M.P.L. Brito, B.A.T. Gouveia, D.J.G. Sousa, \& C.S. Alves 2010, Automatic monitoring and control of museums' environment based on Wireless Sensor Networks, EJSE Special Issue: Wireless Sensor Networks and Practical Applications ;p 1234

Perveen S., K. I. Shinwari and M. Jan 2013, Low temperature stress induced changes in biochemical parameters, protein banding pattern and expression of Zat12 and Myb Genes in Rice Seedling ,Journal of Stress Physiology \& Biochemistry, Vol. 9 No. 42013.

Petruzella F. D. 2010, Electric motors and control systems, McGrawHill, a business unit of The McGraw-Hill Companies, Inc., 1221 Avenue of the Americas, New York, NY, 10020. https://sarviechousite.files.wordpress.com/2015/10/electric-motorsand-control-systems.pdf

Rau P., Y. Gong, Y. Dai, and C. Cheng 2015, Promote Energy Conservation in Automatic Environment Control, Conference: the 33rd Annual ACM Conference Extended Abstracts:Pp 1501-1506

Rodríguez V. M., P. Soengas, V. A. Villaverde, T. Sotelo, M. E. Cartea1 and P. Velasco 2015, Effect of temperature stress on the early vegetative development of Brassica oleracea, BMC Plant 
Biology (2015) 15:145 BMC Plant Biol. 2015 Jun 16;15:145. doi: 10.1186/s12870-015-0535-0.

Rykaczewska K. 2017, Impact of heat and drought stresses on size and quality of the potato yield, Plant Soil Environ. Vol. 63, No. 1:Pp40-46

SAS 2001, User's guide. Statistic. Ver.8.02, SAS Institute Inc., Cary, NC, USA

Toutenburg H. and Shalabh 2009, Statistical analysis of designed experiments, Third Edition, publisher (Springer Science+Business Media, LLC, 233 Spring Street, New York, NY 10013, USA).

Xu C., Y. Chen, L. Zhang and Z. Liu 2016, Design of intelligent control system of transformer oil Temperature, (IJACSA) International Journal of Advanced Computer Science and Applications, Vol. 7, No. 2:Pp 309-313.

Yang, S. and D. S. Simbeye 2013, Computerized greenhouse environmental monitoring and control system based on LabWindows/CVI, JOURNAL OF COMPUTERS, VOL. 8, NO. 2:Pp399-408

Young H. D., R. A. Freedman and A. L. Ford 2008, University Physics, 12th Edition, Pearson Edition, Inc., Wesley , 1301 Sansome ST. CA 941111, USA.

\section{الملخص العربي}

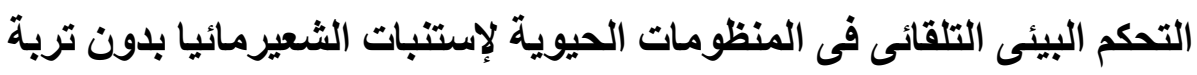

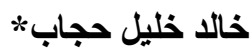

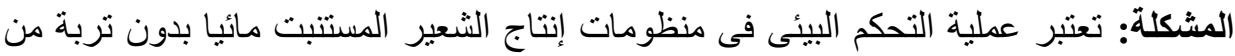

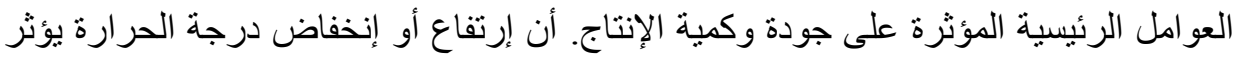

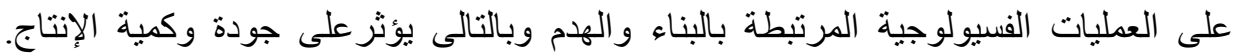

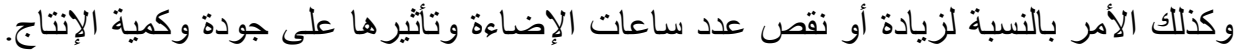

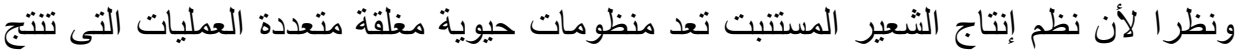
حر ارة ورطوبة و غازات بصورة مستمرة فإنه يستحيل التحكم فيه بطريقة يدوية. وأن أصناف

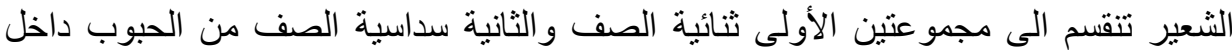
السنبلة. وحتى تاريخه لم تحدد الظروف البيئية المناسبة لإستنبات أى من المجمو عتين.

* قسم الهندة الزراعية ـ كلية الزراعة - جامعة القاهرة. 


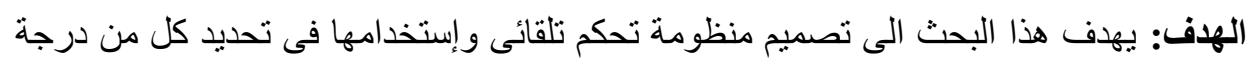

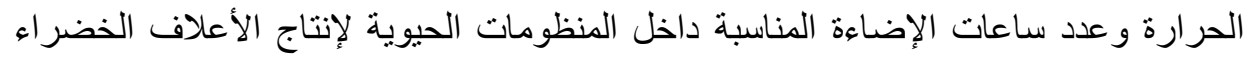

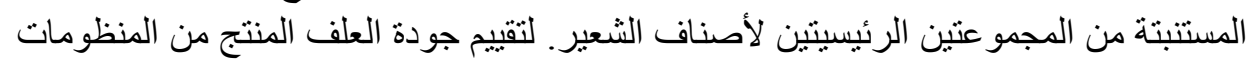
الحيوية، تم تصميم و اجر اء تجربة نمو على قطيع من أربعة لاصنية مجمو عات من الأغنام.

المنهج: لتحقيق الهدف المنشود تم تصميم منظومة تحكم تلقائى لضبط درجة الحرارة و وعدد

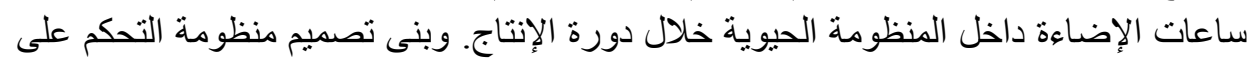

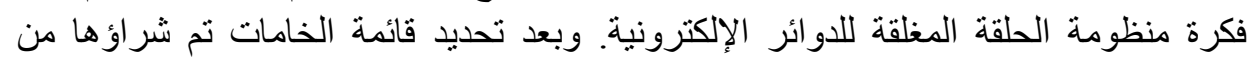

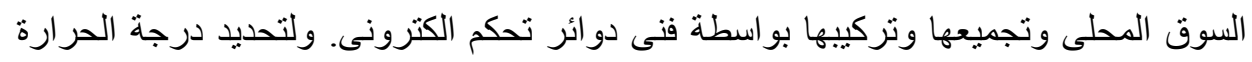

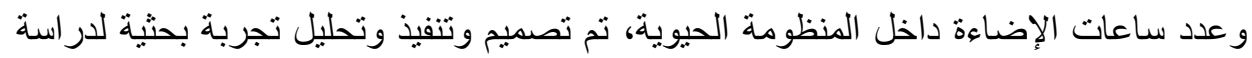

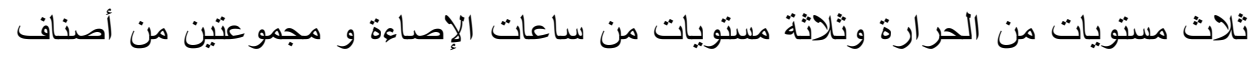

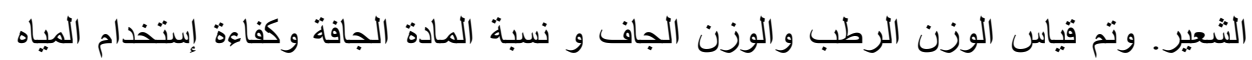

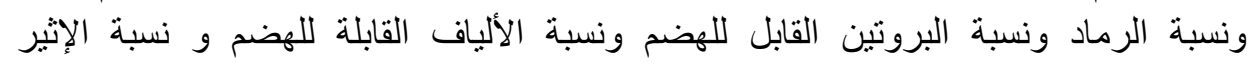
المستخلص و النيتروجين الخالى من الإثير.

النتائج: أوضحت نتائج التحليل الإحصائى للبيانات أن ضبط بيئة المنظومة الحيوية على درجة إنساءة

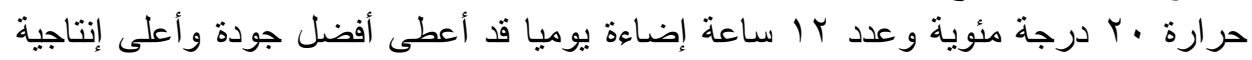

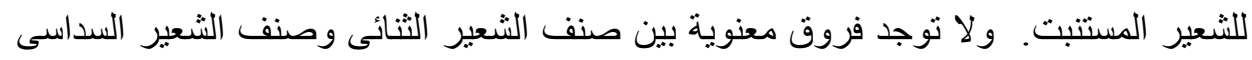

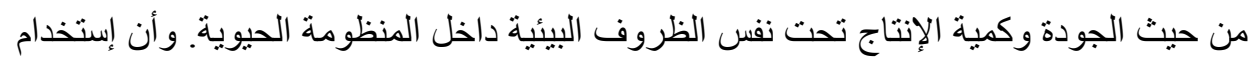

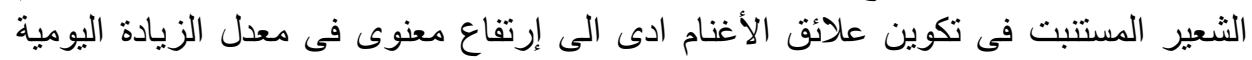

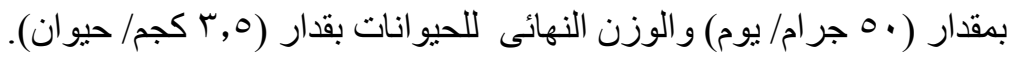

